\title{
MICROBIOLOGICAL ACTIVITIES IN MOONMILK MONITORED USING ISOTHERMAL MICROCALORIMETRY (CAVE OF VERS CHEZ LE BRANDT, NEUCHATEL, SWITZERLAND)
}

\author{
Olivier Braissant ${ }^{*}$, Saskia Bindschedler ${ }^{2}$, Alma U. Daniels ${ }^{1}$, Eric P. Verrecchia ${ }^{2}$, and \\ Guillaume Cailleau²
}

\begin{abstract}
Studies of the influence of microbial communities on calcium carbonate deposits mostly rely on classical or molecular microbiology, isotopic analyses, and microscopy. Using these techniques, it is difficult to infer microbial activities in such deposits. In this context, we used isothermal microcalorimetry, a sensitive and nondestructive tool, to measure microbial activities associated with moonmilk ex-situ. Upon the addition of diluted LB medium and other carbon sources to fresh moonmilk samples, we estimated the number of colony forming units per gram of moonmilk to be $4.8 \times 10^{5}$ $\pm 0.2 \times 10^{5}$. This number was close to the classical plate counts, but one cannot assume that all active cells producing metabolic heat were culturable. Using a similar approach, we estimated the overall growth rate and generation time of the microbial community associated with the moonmilk upon addition of various carbon sources. The range of apparent growth rates of the chemoheterotrophic microbial community observed was between 0.025 and $0.067 \mathrm{~h}^{-1}$ and generation times were between 10 and 27 hours. The highest growth rates were observed for citrate and diluted LB medium, while the highest carbon-source consumption rates were observed for low molecular weight organic acids (oxalate and acetate) and glycerol. Considering the rapid degradation of organic acids, glucose, and other carbon sources observed in the moonmilk, it is obvious that upon addition of nutrients during snow melting or rainfall these communities can have high overall activities comparable to those observed in some soils. Such communities can influence the physico-chemical conditions and participate directly or indirectly to the formation of moonmilk.
\end{abstract}

\section{INTRODUCTION}

Many biogeochemical processes involving many different microbial activities take place in caves (see Barton and Northup, 2007, and Northup and Lavoie, 2001, for reviews). Most of these microbial processes are slow due to the oligotrophic nature of cave environments (Mulec, 2008). Among the results of these processes, moonmilk is an ubiquitous cave deposit composed of various mineral components, such as needle-fiber calcite (NFC) and nanofibers. Both biotic and abiotic mechanisms have been proposed for the development of moonmilk, and multiple mechanisms are possible, but moonmilk is generally believed to be the result of microbial activity (Cañaveras et al., 2006; Mulec et al., 2002). This deposit has strong similarities with secondary calcium carbonate accumulations observed in soils that are mainly composed of NFC and nanofibres. Many papers have provided strong supporting evidence for the biogenic origin of NFC in soils (Callot et al., 1985; Phillips et al., 1987; Phillips and Self, 1987; Cailleau et al., 2009a,b; Curry et al., 2009). Moreover, recent investigations emphasize the potential implication of organic templates as a precursor to mineralized nanofibres (Cailleau et al., 2009b; Bindschedler et al., 2010). However, the biogenic origin is still debated for both moonmilk and soil secondary calcitic deposits composed of NFC and nanofibres (Lacelle, 2010; Borsato et al., 2000; Engel and Northup, 2008). In order to investigate the biogenic origin of moonmilk, many studies have used electron microscopy, bacterial cultures, or both (Cañaveras et al., 2006; Mulec et al., 2002; Cailleau et al., 2009a,b; Bindschedler et al., 2010). Electron microscopy of natural moonmilk samples provides useful information on the spatial relationship between microorganisms and calcium carbonate needles and nanofibres, but it must be recognized that only a limited number of samples can be observed, which leads to conclusions potentially speculative. Similarly, culture-based methods provide great insight into potentially involved microbial processes. For example, culture methods were used to show the ability of soil bacteria to precipitate calcium carbonate (Boquet et al.,

\footnotetext{
* Corresponding Author: olivier.braissant@unibas.ch

${ }^{1}$ Laboratory of Biomechanics \& Biocalorimetry, c/o Biozentrum/Pharmazentrum, University of Basel, Klingelbergstrasse 50-70, CH-4056 Basel, Switzerland

${ }^{2}$ Institute of Geology and Paleontology, University of Lausanne, Quartier UNILDorigny, Bâtiment Anthropole, CH-1015 Lausanne, Switzerland
} 
1973). However, a large part of the microbial population cannot be cultivated, and therefore, are not taken into account (Amman et al., 1995). Finally, nucleic acid-based studies provide insight on the microbial community, but it is often difficult to infer population sizes and specific activities from molecular data unless one uses stable isotope probing (Konhauser, 2007).

In this context, isothermal microcalorimetry can provide another valuable tool for obtaining data on microbial activities associated with moonmilk. Isothermal microcalorimetry is an efficient means of monitoring microbial activities through measurement of heat production rates. Isothermal microcalorimetry is extremely sensitive, and heat flows as low as 20 to $200 \mathrm{nW}$ are sufficient to produce a reliable signal (Braissant et al., 2010; Wadsö, 2002). Assuming that a typical single bacterial cell produces about $2 \mathrm{pW}$ when active (Higuera-Guisset et al., 2005; James, 1987), only 10,000 to 100,000 bacteria per sample (i.e., per 3 or $4 \mathrm{ml}$ microcalorimetric ampoule) are required to produce a detectable signal in most commercial isothermal microcalorimeters. Since only heat production is measured, isothermal microcalorimetry is non-destructive and noninvasive, allowing samples to be studied ex-situ without disturbance other than placing them in the calorimetric vessel. Although these are still significant interactions, they can be considered minimal compared to other techniques. Due to these advantages, isothermal microcalorimetry has been widely used for soils (Rong et al., 2007; Wadsö, 2009), but it had not yet been applied to caves.

In this study, we investigated the microbial activities in moonmilk supplemented with different carbon sources. From the data, the number of active bacteria and the various substrate degradation rates are inferred. This approach provides a valuable set of data that complement previous studies on moonmilk and biomineralization.

\section{Materials And Methods}

\section{Geological Settings}

Vers chez le Brandt $\left(46^{\circ} 56^{\prime} 16^{\prime \prime} \mathrm{N}, 6^{\circ} 28^{\prime} 22^{\prime \prime} \mathrm{E}\right)$ is a limestone cave (Sequanian stage) located in the Swiss Jura mountains $4 \mathrm{~km}$ north of the village of Les Verrières (Fig. 1A) and only 1200 meters from the French border. The cave is 63 meters deep and 336 meters long (Fig. 1B) and has been previously described (Gigon et al., 1976). The average temperature in the cave is about $10{ }^{\circ} \mathrm{C}$ (Perrin, 2003).

\section{SAmple Collection}

Moonmilk samples from the location indicated in Figure 1B were collected aseptically on July 17, 2009. Although moonmilk can be found in most of the cave, this location was chosen because it is less accessible and thus less contaminated. All the material used was sterile, and samples were placed into sterile sampling bags or sterile $50 \mathrm{ml}$ polypropylene tubes. Approximately $100 \mathrm{~g}$ of slightly wet material was collected. Samples were stored in a cooler containing blue ice, and later at $4{ }^{\circ} \mathrm{C}$ until analysis. Samples collected for microcalorimetry were processed and incubated in the microcalorimeter within twenty hours after collection. Additional moonmilk samples were collected for microscopic observations and were stored at $4{ }^{\circ} \mathrm{C}$ for one week before preparation and observation. These samples were taken from specific moonmilk patches selected for their darker color, which we assumed to have slightly higher amounts of organic matter (authors' personal observations; no organic matter measurements were performed in this cave). Organic matter is likely brought to the cave through rock fractures (Perrin 2003). As we did not expect to find a lot of microbes in oligotrophic moonmilk deposits, so these spots with putatively more organic matter were considered to potentially have a greater number of microbes.

\section{Microcalorimetric Analysis}

Moonmilk samples were prepared as described below and introduced into the microcalorimeter (TAM 48, Waters/TA, Delaware) and kept in the equilibration position, inside the microcalorimeter but not in contact with the thermopile that is the sensing element, for 15 minutes to ensure preliminary thermal equilibration. Then, samples were lowered into the measuring position in contact with the thermopile. Sufficient thermal equilibration was achieved after 45 minutes, and heat flow measurements started approximately one hour after insertion into the microcalorimeter and lasted for about 5 days. All samples, controls, and blanks were measured in triplicate unless stated otherwise. All isothermal microcalorimetry measurements were performed at $25{ }^{\circ} \mathrm{C}$ because of the technical limitations of our microcalorimeter, which cannot be operated at cave temperatures (most calorimeters operate at room temperature or above). Therefore a temperature close to that used in many other studies was chosen (Laiz et al., 2000).

\section{Estimation of the Number of Microbial Cells \\ Present in THe MoOnmilk}

Samples of moonmilk were coarsely ground and homogenized in a sterile Petri dish using a sterile scalpel blade. To estimate the number of active cells in the moonmilk, ampoules filled with $2 \mathrm{~g}$ of this coarsely ground moonmilk were prepared and supplemented with $800 \mu \mathrm{l}$ of $50 \times$ diluted LB (Difco - tryptone $0.2 \mathrm{~g} \mathrm{~L}^{-1}$, yeast extract $0.1 \mathrm{~g} \mathrm{~L}^{-1}, \mathrm{NaCl} 0.1 \mathrm{~g} \mathrm{~L}^{-1}$ ) as the carbon sources available in this medium will support growth of many chemoheterotrophic microorganisms. Following the addition of medium, the prepared ampoules were sealed and microcalorimetric measurements were performed at $25{ }^{\circ} \mathrm{C}$ as described above. In addition to the microcalorimetric measurements, plate counts were performed on $50 \times$ diluted LA medium (Difco - tryptone $0.2 \mathrm{~g} \mathrm{~L}^{-1}$, yeast extract $0.1 \mathrm{~g} \mathrm{~L}^{-1}, \mathrm{NaCl} 0.1 \mathrm{~g} \mathrm{~L}^{-1}$, agar $\left.15 \mathrm{~g} \mathrm{~L}^{-1}\right)$ and on $10 \times$ diluted R2A medium (Bacto Peptone $0.05 \mathrm{~g} \mathrm{~L}^{-1}$, Bacto 
Microbiological activities in MOONMilk monitored using isothermal microcalorimetry (CAVE of Vers Chez LE Brandt, Neuchatel, Switzerland)
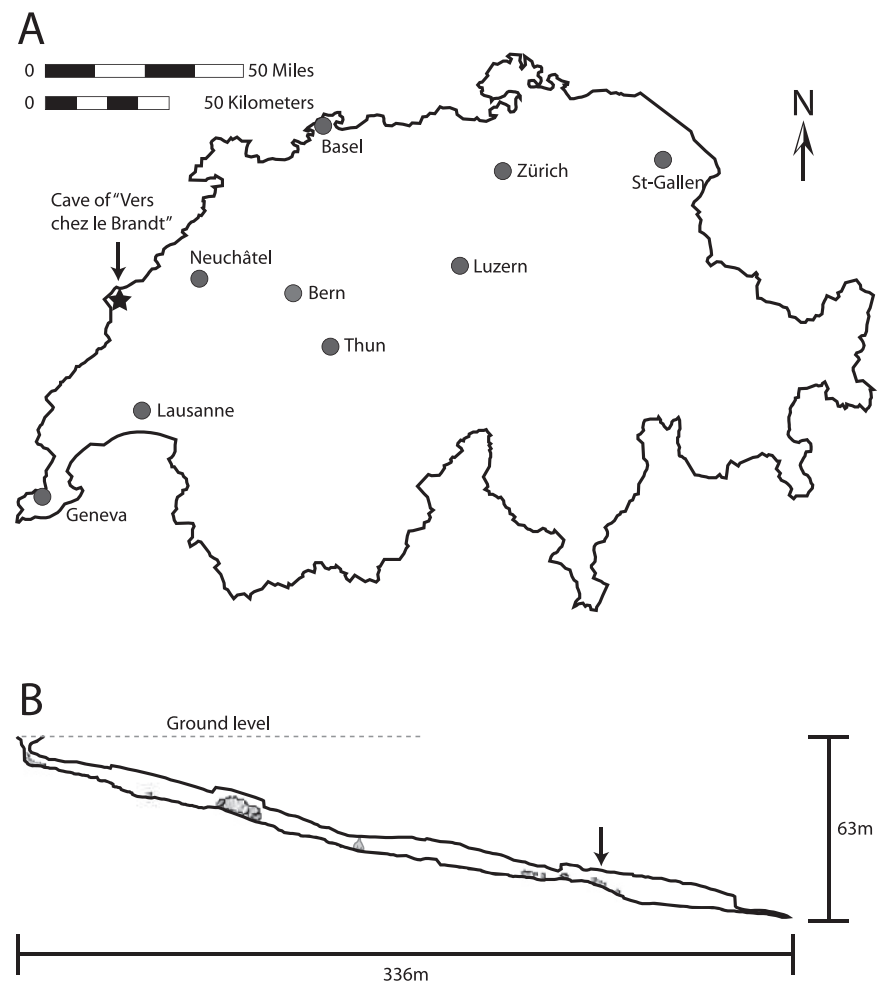

Figure 1. A. Switzerland map indicating the location of the Vers chez le Brandt cave (star) and Swiss main cities (dots). Note that the cave is located only $1200 \mathrm{~m}$ from the French border. B. Horizontal profile of the cave. The arrow indicates the sampling site. Grey shaded areas indicate the presence of large boulders.

yeast extract $0.05 \mathrm{~g} \mathrm{~L}^{-1}$, Bacto casamino acids $0.05 \mathrm{~g} \mathrm{~L}^{-1}$, glucose (Fluka) $0.05 \mathrm{~g} \mathrm{~L} \mathrm{~L}^{-1}$, soluble starch (Fluka) $0.05 \mathrm{~g} \mathrm{~L}^{-1}, \mathrm{KH}_{2} \mathrm{PO}_{4}$ (Fluka) $0.03 \mathrm{~g} \mathrm{~L}^{-1}, \mathrm{MgSO}_{4} \cdot 7 \mathrm{H}_{2} \mathrm{O}$ (Fluka) $0.005 \mathrm{~g} \mathrm{~L}^{-1}$, Bacto agar $15 \mathrm{~g} \mathrm{~L}^{-1}$ ). Diluted media have previously been shown to be appropriate for plate counts of microorganisms from oligotrophic water (Kawai et al., 1999; Janssen et al., 2002; Bull, 2004; Segawa et al., 2011). All agar plates were incubated at $25^{\circ} \mathrm{C}$ for the same time period as the microcalorimetric measurements (i.e., 5 days) to obtain results comparable to those obtained using microcalorimetry. Sterility controls were performed using uninoculated plates for each medium.

A similar experiment was performed to establish controls allowing quantification of the number of cells present in the moonmilk. Bacillus subtilis was chosen as the control because of its ability to consume a wide range of carbon sources and its structural and metabolic similarities with the actinobacteria commonly found in caves. In addition, B. subtilis is easier to handle, compared to filamentous actinobacteria. Ampoules were filled with $2 \mathrm{~g}$ of coarsely ground moonmilk and autoclaved twice at 5 to 6 hours intervals. These ampoules were inoculated with a serial dilution of a suspension of Bacillus subtilis (NEU 16
- Neuchâtel University culture collection) in $50 \times$ diluted LB. The B. subtilis suspension was prepared by centrifugation of an overnight culture grown in $10 \times$ diluted LB. The pellet was then resuspended in $50 \times$ diluted LB. This operation was repeated twice to ensure that only $50 \times$ diluted LB remained. Finally the prepared ampoules were sealed and microcalorimetric measurements were performed at $25{ }^{\circ} \mathrm{C}$ as described above. Blanks were prepared similarly, except no cells were added. Plate counts were performed on LA medium (Difco - tryptone $10.0 \mathrm{~g} \mathrm{~L}^{-1}$, yeast extract $5.0 \mathrm{~g} \mathrm{~L}^{-1}, \mathrm{NaCl} 10.0 \mathrm{~g} \mathrm{~L}^{-1}$, agar $15 \mathrm{~g} \mathrm{~L}^{-1}$ ) to estimate the number of colony forming units introduced into the ampoules.

Measurement of Microbial Activities in Moonmilk

Two grams of coarsely ground-up moonmilk were placed in a calorimetric ampoule and supplemented with $800 \mu \mathrm{l}$ of chosen carbon sources. Unless stated otherwise, all the carbon sources and antibiotics were obtained from Fluka (Switzerland). The carbon sources at $0.3 \mathrm{mg} \mathrm{mL}^{-1}$ were glucose, glycerol, mannitol, Na-oxalate, Na-citrate, Na-acetate, xanthan, starch, humic acids (saturated solution), 50× diluted LB (Difco), and 50× diluted LB supplemented with a final concentration of $50 \mu \mathrm{g} \mathrm{mL} \mathrm{m}^{-1}$ of chloramphenicol. All carbon sources and dehydrated media were prepared in deionized water. Controls were performed using autoclaved deionized water, and blanks were performed using moonmilk autoclaved twice (25 minutes at $121{ }^{\circ} \mathrm{C}$ at 5 to 6 hours intervals) supplemented with sterile $50 \times$ diluted LB. Preliminary tests have shown that $800 \mu \mathrm{l}$ of solution is sufficient to wet the sample homogenously without accumulation of solution at the bottom of the samples. Finally, samples were sealed and introduced in the isothermal microcalorimeter.

Apparent microbial growth rate and generation time were calculated for the different carbon sources according to the method previously described in Kimura and Takahashi (1985) and in Barros et al. (1999).

\section{Scanning Electron Microscopy (SEM)}

Samples were kept at $4{ }^{\circ} \mathrm{C}$ during one week prior to SEM observations. Observations were performed using a Tescan Mira LMU scanning electron microscope. Samples were fixed with osmium tetroxide vapors, freeze-dried, and coated with gold $(18 \mathrm{~nm})$ and carbon $(5 \mathrm{~nm})$. Observations were performed at a distance of $10 \mathrm{~mm}$ and at 10 or $15 \mathrm{kV}$ accelerating voltage, depending on charging artifacts.

\section{RESULTS}

\section{Estimation of the Number of Microbial Cells \\ Present In The Moonmilk}

By using Bacillus subtilis, a typical soil bacterium, in autoclaved calorimetric ampoules containing sterilized moonmilk, under the experimental conditions described above, we estimated that one colony-forming unit gener- 


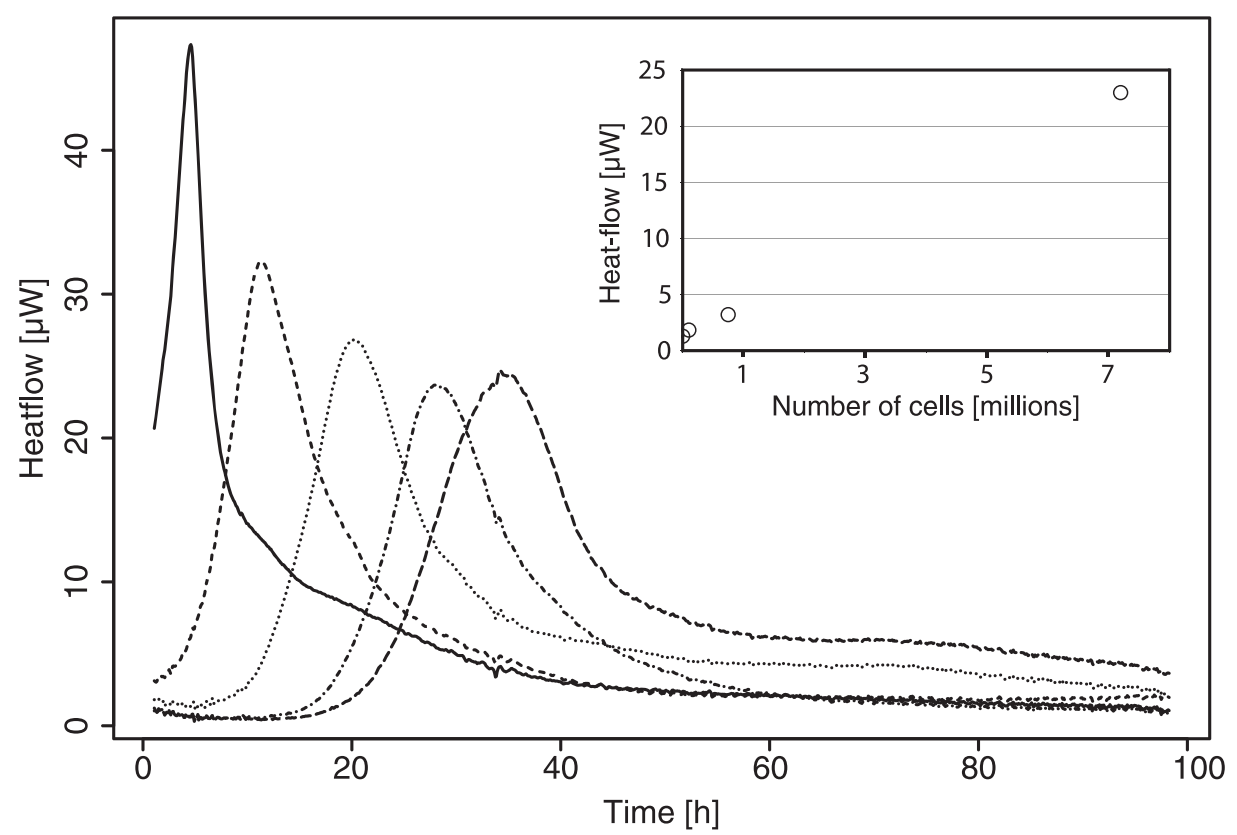

Figure 2. Heat flow pattern generated by the growth of serial 10 -fold dilutions in $50 \times$ diluted LB of Bacillus subtilis added to sterilized moonmilk. Inside panel shows the relationship between the number of cells and the heat flow generated during the first hour, allowing an estimate of the thermal power of one colony forming unit. The curve for the most cells is the one with the left-most peak.

ated a heat flow of $3.0 \mathrm{pW}$ (Fig. 2). This value is based on the first hour of recorded data. During this time, changes in heat flow were less than $5 \%$ of the initial value; therefore we made the assumption that the number of CFU did not significantly increase. It is also in accordance with the range given for bacteria by James (1987). A clear time delay until maximum activity indicated by the heat flow is visible with decreasing number of cells (Fig. 2). Similarly, a slight decrease of maximum activity with decreasing inoculum is also observed (Fig. 2). It is likely that the bacteria at lower densities did not have access to all the substrate for geometric reasons. In addition, recycling of part of the introduced biomass might explain the higher heat flow observed at high densities. Therefore, both of these factors, restrained access to carbon sources and biomass recycling, are likely to explain the observed decreasing trend. However, the total heat produced after 100 hours (i.e., the integral of the heat flow curve over 100 hours) was mostly constant, with an average of $2.2 \pm$ $0.3 \mathrm{~J}(\mathrm{n}=18)$, showing that substrate consumption was essentially similar in all the samples.

Upon addition of $50 \times$ diluted LB medium to fresh moonmilk samples, we estimated that the amount of active chemoheterotrophic cells per gram of moonmilk from Vers chez le Brandt cave is $4.8 \times 10^{5} \pm 0.2 \times 10^{5}$ active microbial CFU ( $n=5)$. This estimation is of course dependant on the estimation of the thermal power of one CFU.

Plate counts on $50 \times$ diluted LA and $10 \times$ diluted R2A media incubated over 5 days show counts of the same order of magnitude $\left(7.7 \times 10^{5} \pm 2.4 \times 10^{5}\right.$ and $7.8 \times 10^{5} \pm 2.9 \times$ $10^{5} \mathrm{CFU}$ per gram of moonmilk, respectively). Although higher, these values are in the same range compared to the microcalorimetric data. It is noteworthy that the proportion of actinobacteria determined microscopically on these plates were $81 \% \pm 19 \%$ on $50 \times$ diluted LB and $94 \% \pm 6 \%$ on $10 \times$ diluted R2A. This observation is in agreement with previous report of the association of actinobacteria with moonmilk (Cañaveras et al., 2006), SEM observations, and the strong oxalate-degrading activities measured (see below).

\section{Microbial Activities in Moonmilk}

Addition of the various carbon sources resulted in an increase in heat flow, indicating an increase in microbial activity. This increase is usually observed after a lag phase up to 30 hours. After reaching a maximum, the heat flow decreases back to values close to the initial values. The resulting heat flow pattern is characterized by a single peak, usually showing a small shoulder (Fig. 3), except in the case of $50 \times$ diluted LB, where two clearly separated peaks are observed (Fig. 3A).

Strong differences are observed between heat flow patterns resulting from the addition of the various carbon sources (Fig. 3). A determination of the apparent growth rate and generation time (Table 1) clearly shows the differences in microbial stimulation generated by the different carbon sources. In the conditions of the experiment, citrate, diluted LB medium, xanthan, glucose, starch, 
Microbiological activities in MOONMilk monitored using isothermal microcalorimetry (CAVE of Vers Chez LE Brandt, Neuchatel, Switzerland)
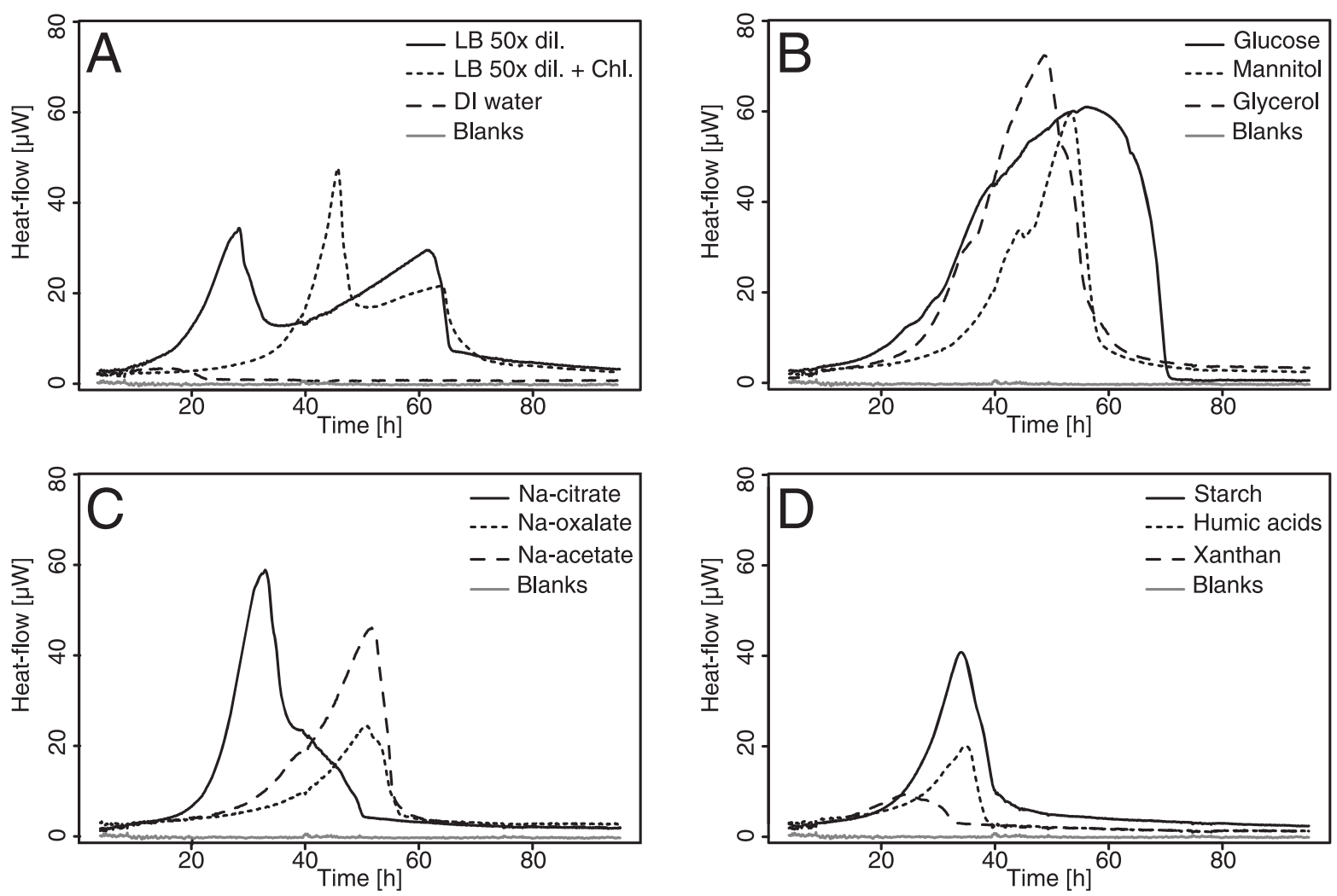

Figure 3. Representative heat flow patterns generated by the addition of various carbon sources to moonmilk. A. Moonmilk samples supplemented with $50 \times$ diluted LB medium and 50× diluted LB medium supplemented with chloramphenicol and deionized water. B. Moonmilk supplemented with glucose and poly-alcohols. C. Moonmilk supplemented with organic acids. D. Moonmilk supplemented with polymers.

and glycerol supported a higher apparent growth rate than humic acids, mannitol, acetate, and oxalate. Deionized water addition resulted in very little heat flow increase, possibly due to the dissolution of carbonate minerals or desorption processes releasing a very small amount of nutrients. A small rise in the heat flow was not observed when autoclaved moonmilk was supplemented with either diluted LB or deionized water, emphasizing the fact that it is most likely related to a biological process. On the other hand, consumption rates show a different picture. The maximum consumption rates were calculated assuming the chemical equations listed in Table 2. An obvious trend appears when plotting Gibbs free energy available versus consumption rate (Fig. 4; $r=0.95, n=6, p<0.05$ ). The highest calculated consumption rate is given by the oxalate substrate and is in agreement with the high numbers of actinobacteria observed in the plate counts. This group of bacteria is known for its great ability to degrade oxalate (Sahin, 2003; 2004).

A much longer lag (about 20 hours longer) is observed after addition of $50 \times$ diluted LB containing chloramphenicol (Fig. 3). Nevertheless, the resulting heat flow pattern looks similar, although contracted in time. This result demonstrates that a rather large portion of the microbial community is sensitive to chloramphenicol and may show that there is little fungal activity, because fungi should not be sensitive to such chloramphenicol concentration.

\section{ELECTRON Microscopy}

Electron microscopy of the moonmilk samples revealed the presence of numerous morphotypes of microorganisms. Most observations show filamentous microorganisms. According to their morphology, these microorganisms could most likely be related to actinobacteria and their arthrospores (Fig. 5B, C). This is in agreement with our observations on agar plates. Other filamentous organisms, showing resemblance to hyphomicrobiaceae, are also observed (Fig. 5D). Finally, larger filaments, branched or not, are interpreted as fungi (Fig. 5E, F). Most microorganisms were observed at the surface of aggregates of intact samples of moonmilk aggregates. In contrast, observations performed on cut or coarsely ground moonmilk samples show fewer microorganisms. Considering the slow growth rate observed, even under the addition of carbon sources, and the slow appearance of colonies in the laboratory, it is likely that the bacterial morphotypes observed here belong to our sample. However, the possibility of some growth during the storage of the samples cannot be completely dismissed. 
Table 1. Apparent growth rate of the microbial community when exposed to different substrates. The growth rate and generation time were determined using isothermal microcalorimetry data for the different carbon sources according to the method previously described in Kimura and Takahashi (1985) and in Barros et al. (1999).

\begin{tabular}{lcc}
\hline Carbon source & Growth rate, $\mathrm{h}^{-1}$ & Generation time, $\mathrm{h}$ \\
\hline Oxalate & $0.0253 \pm 0.0003$ & $27.4 \pm 0.3$ \\
Acetate & $0.0332 \pm 0.0037$ & $21.0 \pm 2.4$ \\
Glycerol & $0.0456 \pm 0.0041$ & $15.3 \pm 1.4$ \\
Citrate & $0.0668 \pm 0.0075$ & $10.4 \pm 1.2$ \\
Glucose & $0.0506 \pm 0.0073$ & $13.9 \pm 2.0$ \\
Mannitol & $0.0336 \pm 0.0009$ & $20.7 \pm 0.6$ \\
Xanthan & $0.0565 \pm 0.0034$ & $12.3 \pm 0.7$ \\
Starch & $0.0474 \pm 0.0025$ & $14.7 \pm 0.8$ \\
Humic acids & $0.0369 \pm 0.0008$ & $18.8 \pm 0.4$ \\
LB50x & $0.0579 \pm 0.0051$ & $12.0 \pm 1.1$ \\
\hline
\end{tabular}

\section{Discussion}

Our microcalorimetric data clearly show that microbial activity can easily and accurately be measured in the moonmilk samples during ex-situ analyses. In addition, the numbers of colony-forming units of cultivable bacteria estimated by plate counts after 5 days and by microcalorimetry are in agreement. However, the relationship between the plate count and the microcalorimetric estimates should be considered with care, since one cannot be sure that all the bacteria that produced metabolic heat upon addition of $50 \times$ diluted LB are cultivable. Viable but not culturable cells might have contributed to the heat production. Indeed, after 32 days of incubation, numbers of culturable bacteria measured on the agar plates increased to $9 \times 10^{6} \mathrm{CFU}$ per gram of moonmilk, and showed no further increase (data not shown). Therefore, the measured $4.8 \times 10^{5}$ active CFU per gram of moonmilk would represent only $5.3 \%$ of the total number of cultivable bacteria and an even smaller fraction of the total bacteria,

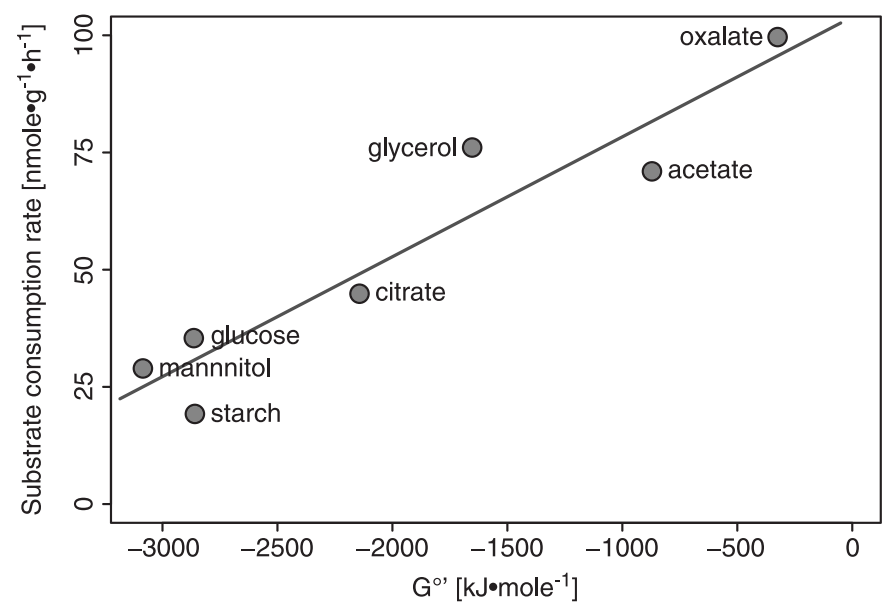

Figure 4. Relationship between Gibbs free energy of the substrates' oxidation and their maximum consumption rate.

including those not culturable. In addition, the discrepancy between microcalorimetric estimates and plate counts at 5 and 32 days suggests that a rather large proportion of the bacteria might be dormant. This dormant fraction could be actinobacteria arthrospores (Goodfellow and Williams, 1983), but could also include dormant cells sensu stricto with no visible activity (Costerton et al., 1995). These dormant cells are common at very low growth rates (Pirt 1987) and may contribute to the maintenance of microbial diversity in oligotrophic environments (Jones and Lennon 2010). In oligotrophic environments such as a cave, lack of nutrients is likely to be the main cause of dormant or nonculturable states (Colwell and Grimes, 2000).

These discrepancies emphasize the limitations of isothermal microcalorimetry. Indeed microcalorimetry is a blind tool that only measures heat production rate; in this study metabolic heat production rate. To get a better picture of microbial processes in moonmilk, microcalorimetry should be coupled with other tools, allowing an estimate of the microbial population size. In addition, the composition of the community, determined by molecular

Table 2. Consumption rates of the various carbon sources calculated based on the assumption that only aerobic respiration occurred. Equations are listed with the thermodynamic parameters used to convert maximum heat flow (W or $\mathrm{J} \mathrm{s}^{-1}$ ) into substrate consumption rate (nmoles $h^{-1} g^{-1}$ ).

\begin{tabular}{llccc}
\hline Equation & $\begin{array}{c}\text { Substrate } \\
\text { common name }\end{array}$ & $\begin{array}{c}\Delta \mathrm{G}^{0 \prime} \\
(\mathrm{KJ} \text { mole }\end{array}$ & $\begin{array}{c}\text { Maximum heat } \\
\text { flow }(\mu \mathrm{W})\end{array}$ & $\begin{array}{c}\text { Substrate maximum } \\
\text { consumption rate } \\
\left(\mathrm{nmoles} \mathrm{h}^{-1} \mathrm{~g}^{-1}\right)^{\mathrm{a}}\end{array}$ \\
\hline $2 \mathrm{C}_{2} \mathrm{H}_{2} \mathrm{O}_{4}+\mathrm{O}_{2} \rightarrow 4 \mathrm{CO}_{2}+2 \mathrm{H}_{2} \mathrm{O}$ & oxalate & -328 & $18 \pm 2$ & $98 \pm 11$ \\
$\mathrm{C}_{2} \mathrm{H}_{4} \mathrm{O}_{2}+2 \mathrm{O}_{2} \rightarrow 2 \mathrm{CO}_{2}+2 \mathrm{H}_{2} \mathrm{O}$ & acetate & -872 & $34 \pm 10$ & $71 \pm 21$ \\
$2 \mathrm{C}_{3} \mathrm{H}_{8} \mathrm{O}_{3}+7 \mathrm{O}_{2} \rightarrow 6 \mathrm{CO}_{2}+8 \mathrm{H}_{2} \mathrm{O}$ & glycerol & -1653 & $70 \pm 4$ & $76 \pm 5$ \\
$2 \mathrm{C}_{6} \mathrm{H}_{8} \mathrm{O}_{7}+9 \mathrm{O}_{2} \rightarrow 12 \mathrm{CO}_{2}+8 \mathrm{H}_{2} \mathrm{O}$ & citrate & -2144 & $53 \pm 1$ & $45 \pm 1$ \\
$\mathrm{C}_{6} \mathrm{H}_{12} \mathrm{O}_{6}+6 \mathrm{O}_{2} \rightarrow 6 \mathrm{CO}_{2}+6 \mathrm{H}_{2} \mathrm{O}$ & glucose & -2860 & $57 \pm 1$ & $36 \pm 1$ \\
$2 \mathrm{C}_{6} \mathrm{H}_{14} \mathrm{O}_{6}+13 \mathrm{O}_{2} \rightarrow 12 \mathrm{CO}_{2}+14 \mathrm{H}_{2} \mathrm{O}$ & mannitol & -3081 & $49 \pm 7$ & $29 \pm 4$ \\
$\left(\mathrm{C}_{6} \mathrm{H}_{12} \mathrm{O}_{6}\right)_{\mathrm{n}}+6 \mathrm{O}_{2} \rightarrow 6 \mathrm{CO}_{2}+6 \mathrm{H}_{2} \mathrm{O}^{\mathrm{b}}$ & starch & $-2860^{\mathrm{b}}$ & $31 \pm 2^{\mathrm{b}}$ & $19 \pm 2^{\mathrm{b}}$ \\
\hline
\end{tabular}

${ }^{a}$ Assuming that only the reaction considered takes place.

${ }^{\mathrm{b}}$ Converted into glucose equivalents. 
Microbiological aCtivities in MOONMilk MONitored USing isothermal microcalorimetry (CAVE OF Vers CHEZ LE BRANDT, Neuchatel, Switzerland)


Figure 5. Scanning electron micrographs of moonmilk aggregates and microorganisms found in them. A. General view of the moonmilk sample showing mostly monocrystalline and serrated-edged needle-fiber calcite. B. Growing filamentous microorganisms resembling actinobacteria. C. Chains of cells resembling actinobacteria arthrospores. Note that spores arranged in spirals are usually associated to the genus Streptomyces (see Holt et al., 1994). D. Chain of appendaged bacterium. E. and F. Fungal filaments. 
methods, would allow relating the activities measured to the members of this community. However, in our study, the use of a specific antibiotic allows us to point to possibly important members of the moonmilk population. Upon addition of chloramphenicol, the peak of activity was strongly delayed, but not suppressed. Undoubtedly, a part of the bacterial community present was sensitive to this antibiotic. Since fungi should not be affected by such low concentrations of chloramphenicol, they might be responsible for a part of the remaining activity. Also, considering the wide occurrence of chloramphenicol resistance among actinobacteria (Shaw and Hopwood, 1976) and their high proportion in our samples, it seems that actinobacteria might be a key player in this community. Recent publications have emphasized the importance of Actinobacteria in caves. For example, Laiz et al. (2000) using both cultural and molecular methods to study the microbial community on stalactites, found that about $50 \%$ of the isolated strains were actinomycetes and that the most prominent TGGE band was most likely related to a close relative of Nocardiopsis, another actinobacteria. Similarly, $16 \%$ of a clone library obtained from the walls of a karstic cave in Slovenia were actinobacteria (Pašić et al., 2009), making actinobacteria the second most abundant group after gamma-proteobacteria (about 33\%). Finally, combining molecular DNA and RNA based fingerprinting, targeting the total community and the metabolically active part of the community, respectively, Portillo et al. (2008, 2011) have shown that moonmilk contained a subset of the community present in the white colonization from the Altamira Cave and that actinobacteria, among others, were an important part of the metabolically active microbial population. The authors also report that about $20 \%$ of the community detected through DNA-based fingerprinting remains undetected through RNA-based fingerprinting, emphasizing that a rather large proportion of the community shows undetectable metabolic activity. Furthermore, the nanorespirometry measurements performed in the study performed by Portillo et al. (2011) indicate that once white colonizations are calcified into moonmilk, the metabolic activity decreases by about a factor of 20 .

The microcalorimetric data obtained during this study also show that it is possible to further characterize the metabolically active part of the community by supplementing the moonmilk samples with different carbon sources, indicating the responses of the active part of the microbial community to specific carbon sources. Such response is expressed as the growth rate of the community in response to a carbon source or as the maximum consumption rate of this carbon source. In our study, the calculated apparent growth rates are comparable to growth rates observed in soils (Barros et al., 1995; 1999; Parinkina et al., 1973). However, we have to recognize that the temperature in the microcalorimeter was higher than the cave environment, $25{ }^{\circ} \mathrm{C}$ instead of $10{ }^{\circ} \mathrm{C}$, which might have led to overestimating these growth rates. Nevertheless, our data show clear differences in microbial growth rates observed upon the addition of the different carbon sources.

Similarly, substrate consumption rates of organic acids and glucose calculated in this study are within the range of those observed in forest soils (Fujii et al., 2010; van Hees et al., 2002). Both of these observations suggest that, in this cave, the microbial community can be as active as in soils. One major limitation in such a community is the substrate input that is mainly linked to the leaching of material from the soil above the cave. Such leaching can only occur during rain or storm events and spring snow melt. Therefore, the activity, in the absence of addition of substrate, is extremely low in this nutrient-deficient system (Mulec, 2008). High metabolic and heat-production rates can be measured in caves when the sample is collected from microbial mats (Rohwerder et al., 2003). Although organic acid and glucose have received a lot of attention with respect to their degradation rate in the environment, other carbon sources, such as mannitol, starch, xanthan, or humic acid, have been neglected in the literature. Therefore, we cannot compare their measured degradation and associated apparent growth rates from our study with data from other hypogean environments or soils.

With respect to the formation of moonmilk, these results point to metabolic activities capable of creating conditions favorable for the precipitation of calcium carbonate. Physicochemical characterization of the water percolating in this cave during rainfall has shown that it is undersaturated with respect to calcite (Perrin, 2003), and consequently, able to dissolve carbonate minerals. Similarly, the same study has shown that this percolating water is characterized by an increasing content of total organic carbon. In this context, it can be assumed that the microbial consumption of this organic carbon might provide sufficient carbonate ions and alkalinity to promote calcium carbonate formation. Indeed, the growth of cave microbial populations in a diluted medium such as nutrient broth was shown to increase the $\mathrm{pH}$ to values close to or above carbonate mineral stability (i.e., $\mathrm{pH}=8.4$; Portillo and Gonzalez, 2011). Microbial metabolism of organic acids imported in the system through the percolating water will contribute to the increase in $\mathrm{pH}$ since many organic acids have higher $\mathrm{pHs}$ than carbonic acid. This increase in $\mathrm{pH}$ has previously been demonstrated for oxalate (Braissant et al., 2002, 2004). Similarly, Curry et al. (2009) have demonstrated that use of calcium succinate by bacteria isolated from cottonballs (a specific type of moonmilk) yielded a significant production of calcium carbonate. Turnover of humic acids or exopolymeric substances such as xanthan could also favor the precipitation of carbonate minerals in the same way. In addition, such processes will also favor precipitation of carbonate minerals by releasing the calcium bound to the exopolymers (Braissant et al., 2007; 2009; Dupraz et al., 2009) or the humic acids and by removing precipitation inhibitors.

The large proportion of actinobacteria observed in this study, as well as in others (Laiz et al., 2000; Stomeo et al., 
Microbiological aCtivities in MOONMilk MONitored USing isothermal Microcalorimetry (CAVE OF Vers CHEZ LE Brandt, Neuchatel, Switzerland)
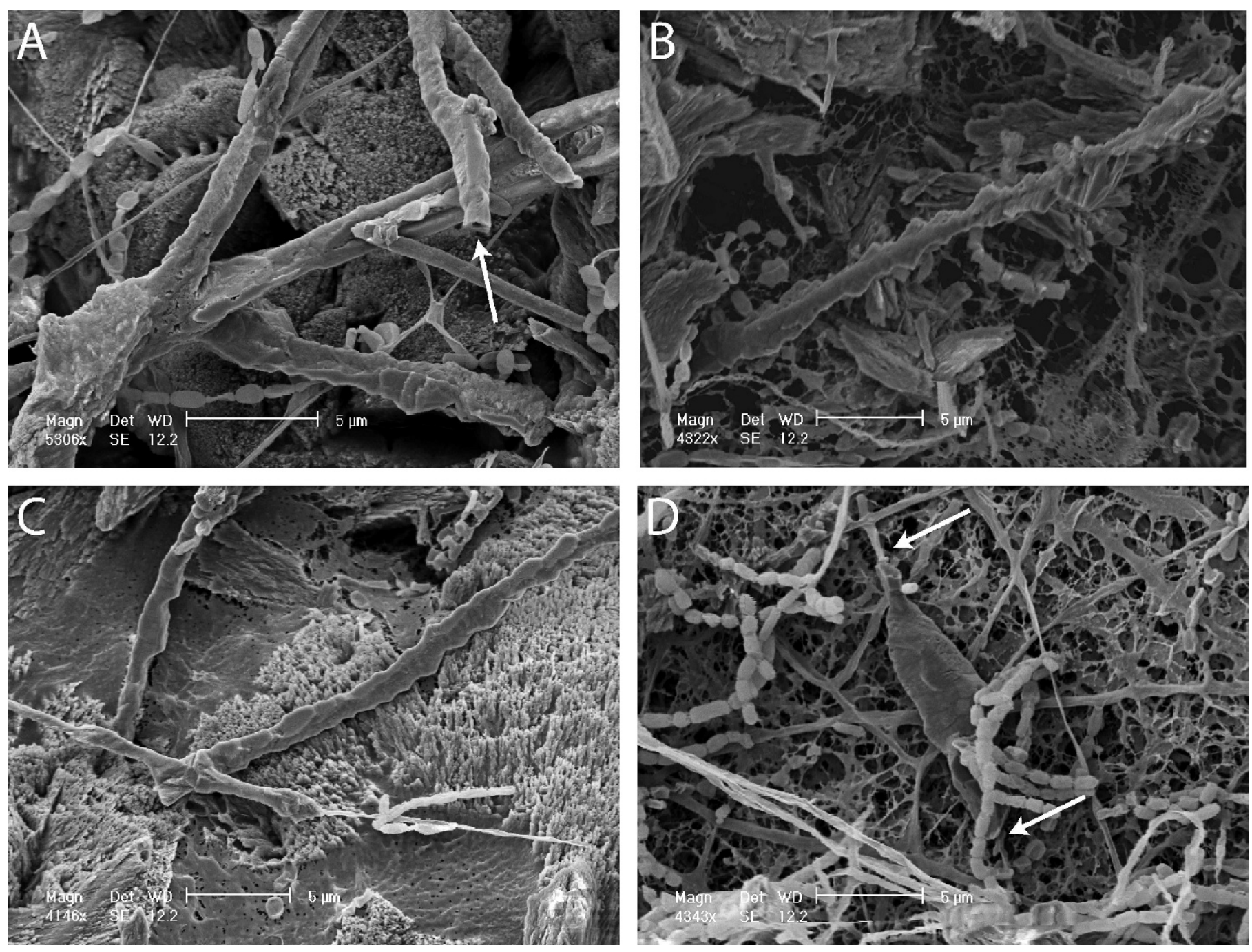

Figure 6. Indurate hyphae and "filament shaped" crystals produced by Streptomyces sp. growing on B4 agar plates. Note the similarities between these crystals and the features that can be observed in moonmilk. A. Typical indurated hyphae with a smooth appearance. A central hole may be seen on these structures (arrow). B. Straight calcified hyphae showing indentations due to epitactic growth of calcium carbonate. C. Curved indurated hyphae showing serrated edges due to epitactic growth of calcium carbonate only on one side. D. Epitaxy forming a large crystal around a mineralized hypha; arrows indicate the hyphae going through the crystal.

2008; Cuezva et al., 2009), and their strong ability to degrade oxalate (Sahin 2003, 2004), exopolymeric substances (Qian et al., 2007; Muchová et al., 2009; Tan et al., 2009; Gaskell et al., 2010), and humic acid (Badis et al., 2009; Dari et al., 1995) emphasize once more their potential role in the formation of moonmilk by creating the necessary physicochemical conditions for carbonate-mineral precipitation. The role of actinobacteria in the formation of moonmilk was previously discussed by Cañaveras et al. (2006). According to their proposed model, the formation of a microbial biofilm would lead to a step-by-step formation of moonmilk using bacterial and/or fungal hyphae as the template. Filamentous actinobacteria were shown to produce needleshaped crystals in cultures, but the needles resulting from such cultures have different sizes and shapes than those observed in moonmilk (Fig. 6). Therefore, another process is thought to be at the origin of the calcitic features observed in the cave Vers chez le Brandt. No biofilm has been observed in the samples collected in that cave, and consequently the model proposed by Bindschedler et al. (2010) or by Cailleau et al. (2009a,b) involving calcite pseudomorphosis of fungal, bacterial, or plant cell-wall fibrous material seems more appropriate in that cave. In addition, the model of Bindschedler et al. (2010) could also explain the formation of nanofibers.

\section{Conclusions}

Microcalorimetric investigations on moonmilk samples allowed us to gain additional insights into the active 
bacterial population as a whole. This study demonstrates that it is possible to estimate the size of the metabolically active microbial population in moonmilk samples. In addition, we determined the growth rate of the metabolically active microbial population with various carbon sources added, as well as the maximum consumption rate of these carbon sources. Obtaining information on growth rates and consumption rates allows for inferring what processes might be important to understanding the microbiology and biogeochemistry of moonmilk. In our study, organic acids were rapidly consumed, with citric acid sustaining the highest growth rate, emphasizing the crucial role of organic-acid input for the carbonate microfabric processes driven by this microbial community. Further use of microcalorimetry, in combination with molecular techniques, will undoubtedly lead to a better understanding of moonmilk formation by linking measurements of the rate and extent of metabolic processes and growth to the composition of the microbial community.

\section{ACKNOWLEDGEMENTS}

The authors wish to thank Dr. Pierre Vonlanthen at IGP UniL for technical support during SEM obsvervations. The authors are also thankful for the valuable comments and suggestions provided by associate editor Dr. K. Lavoie and two anonymous reviewers.

\section{REFERENCES}

Amann, R.I., Ludwig, W., and Schleifer, H.K., 1995, Phylogenetic identification and in situ detection of individual microbial cells without cultivation: Microbiological Reviews, v. 59, p. 143-169.

Badis, A., Ferradji, F.Z., Boucherit, A., Fodil, D., and Boutoumi, H., 2009, Characterization and biodegradation of soil humic acids and preliminary identification of decolorizing actinomycetes at Mitidja plain soils (Algeria): African Journal of Microbiology Research, v. 3, p. $997-1007$.

Barros, N., Feijóo, S., Simoni, J.A., Prado, A.G.S., Barboza, F.D., and Airoldi, C., 1999, Microcalorimetric study of some Amazonian soils: Thermochimica Acta, v. 328, p. 99-103. doi: 10.1016/S00406031(98)00629-7.

Barros, N., Gomez-Orellana, I., Feijbóo, S., and Balsa, R., 1995, The effect of soil moisture on soil microbial activity studied by microcalorimetry: Thermochimica Acta, v. 249, p. 161-168. doi: 10.1016/0040-6031(95)90686-X.

Barton, H.A., and Northup, D.E., 2007, Geomicrobiology in cave environments: past, current and future perspectives: Journal of Cave and Karst Studies, v. 69, p. 163-178.

Bindschedler, S., Millière, L., Cailleau, G., Job, D., and Verrecchia, E.P., 2010, Calcitic nanofibres in soils and caves: a putative fungal contribution to carbonatogenesis, in Pedley, H.M., and Rogerson, M., eds., Tufas and Speleothems: Unraveling the Microbial and Physical Controls: Geological Society of London Special Publications 336, p. 225-238. doi: 10.1144/SP336.11.

Boquet, E., Boronat, A., and Ramos-Cormenzana, A., 1973, Production of calcite (calcium carbonate) crystals by soil bacteria is a general phenomenon: Nature, v. 246, p. 527-529. doi: 10.1038/246527a0.

Borsato, A., Frisia, S., Jones, B., and Van Der Borg, K., 2000, Calcite moonmilk: crystal morphology and environment of formation in caves in the Italian Alps: Journal of Sedimentary Research, v. 70, p. 1171-1182. doi: 10.1306/032300701171.
Braissant, O., Cailleau, G., Aragno, M., and Verrecchia, E.P., 2004, Biologically induced mineralization in the tree Milicia excelsa (Moraceae): its causes and consequences to the environment: Geobiology, v. 2, p. 59-66. doi: 10.1111/j.1472-4677.2004.00019.x.

Braissant, O., Decho, A.W., Dupraz, C., Glunk, C., Przekop, K.M., and Visscher, P.T., 2007, Exopolymeric substances of sulfate-reducing bacteria: Interactions with calcium at alkaline $\mathrm{pH}$ and implication for formation of carbonate minerals: Geobiology, v. 5, p. 401-411. doi: 10.1111/j.1472-4669.2007.00117.x.

Braissant, O., Decho, A.W., Przekop, K.M., Gallagher, K.L., Glunk, C., Dupraz, C., and Visscher, P.T., 2009, Characteristics and turnover of exopolymeric substances in a hypersaline microbial mat: FEMS Microbiology Ecology, v. 67, p. 293-307. doi: 10.1111/j.1574-6941. 2008.00614.x.

Braissant, O., Verrecchia, E.P., and Aragno, M., 2002, Is the contribution of bacteria to terrestrial carbon budget greatly underestimated? Naturwissenschaften, v. 89, p. 366-370. doi: 10.1007/s00114-0020340-0.

Braissant, O., Wirz, D., Göpfert, B., and Daniels, A.U., 2010, Use of isothermal microcalorimetry to monitor microbial activities: FEMS Microbiology Letters, v. 303, p. 1-8. doi: 10.1111/j.1574-6968.2009. 01819.x.

Bull, A.T., 2004, Microbial Diversity and Bioprospecting, Washington, American Society of Microbiology, $496 \mathrm{p}$.

Cailleau, G., Dadras, M., Abolhassani-Dadras, S., Braissant, O., and Verrecchia, E.P., 2009a, Evidence for an organic origin of pedogenic calcitic nanofibres: Journal of Crystal Growth, v. 311, p. 2490-2495. doi: 10.1016/j.jcrysgro.2009.02.029.

Cailleau, G., Verrecchia, E.P., Braissant, O., and Emmanuel, L., 2009b, The biogenic origin of needle fibre calcite: Sedimentology, v. 56, p. 1858-1875. doi: 10.1111/j.1365-3091.2009.01060.x.

Callot, G., Guyon, A., and Mousain, D., 1985, Inter-relations entre aiguilles de calcite et hyphes mycéliens: Agronomie, v. 5, p. 209-216.

Cañaveras, J.C., Cuezva, S., Sanchez-Moral, S., Lario, J., Laiz, L., Gonzalez, J.M., and Saiz-Jimenez, C., 2006, On the origin of fiber calcite crystals in moonmilk deposits: Naturwissenschaften, v. 93, p. 27-32. doi: 10.1007/s00114-005-0052-3.

Colwell, R.R., and Grimes, D.J., 2000, Nonculturable Microorganisms in the Environment, Washington, American Society of Microbiology, $354 \mathrm{p}$.

Costerton, J.W., Lewandowski, Z., Caldwell, D.E., Korber, D.R., and Lappin-Scott, H.M., 1995, Microbial biofilms: Annual Review of Microbiology, v. 49, p. 711-745. doi: 10.1146/annurev.mi.49.100195. 003431.

Cuezva, S., Sanchez-Moral, S., Saiz-Jimenez, C., and Cañaveras, J.C., 2009, Microbial communities and associated mineral fabrics in Altamira Cave, Spain: International Journal of Speleology, v. 38, p. 83-92.

Curry, M.D., Boston, P.J., Spilde, M.N., Baichtal, J.F., and Campbell, A.R., 2009, Cottonballs, a unique subaqueous moonmilk and abundant subaerial moonmilk in Cataract Cave, Tongass National Forest, Alaska: International Journal of Speleology, v. 38, p. $111-128$.

Dari, K., Béchet, M., and Blondeau, R., 1995, Isolation of soil Streptomyces strains capable of degrading humic acids and analysis of their peroxidase activity: FEMS Microbiology Ecology, v. 16, p. 115-122. doi: 10.1111/j.1574-6941.1995.tb00275.x.

Dupraz, C., Reid, R.P., Braissant, O., Decho, A.W., Norman, R.S., and Visscher, P.T., 2009, Processes of carbonate precipitation in modern microbial mats: Earth-Science Reviews, v. 96, p. 141-162. doi:10. 1016/j.earscirev.2008.10.005.

Engel, A.S., and Northup, D.E., 2008, Caves and Karst as Model Systems for Advancing the Microbial Sciences, in Martin, J.B., and White, W.B., eds., Frontiers of Karst Research, Leesburg, Virginia, Karst Waters Institute Special Publication 13, p. 37-48.

Fujii, K., Hayakawa, C., Van Hees, P.A.W., Funakawa, S., and Kosaki, T., 2010, Biodegradation of low molecular weight organic compounds and their contribution to heterotrophic soil respiration in three Japanese forest soils: Plant and Soil, v. 334, p. 475-489. doi: 10.1007/ s11104-010-0398-y.

Gaskell, E.E., Sihanonth, P., Rostron, C., Hutcheon, G.A., and Hobbs, G., 2010, Isolation and identification of mucinolytic actinomycetes: Antonie van Leeuwenhoek, v. 97, p. 211-220. doi: 10.1007/s10482009-9402-z. 
Microbiological aCtivities in MOONMilk MONitored USing isothermal Microcalorimetry (CAVE OF Vers CHEZ LE BRANDT, Neuchatel, Switzerland)

Gigon, R., 1976, Inventaire spéléologique de la Suisse, tome 1, Canton de Neuchâtel, Neuchâtel, Commission de Spéléologie de la Société helvétique des Sciences naturelles, $223 \mathrm{p}$.

Goodfellow, M., and Williams, S.T., 1983, Ecology of actinomycetes: Annual Reviews in Microbiology, v. 37, p. 189-216.

Higuera-Guisset, J., Rodríguez-Viejo, J., Chacón, M., Muñoz, F.J., Vigués, N., and Mas, J., 2005, Calorimetry of microbial growth using a thermopile based microreactor: Thermochimica Acta, v. 427, p. 187-191. doi: 10.1016/j.tca.2004.09.010.

Holt, J.G., Krieg, N.R., Sneath, P.H.A., Staley, J.T., and Williams, S.T., 1994, Bergey's Manual of Determinative Bacteriology, ninth edition, New York, London, Lippincott Williams \& Wilkins, 791 p.

James, A.M., ed., 1987, Thermal and Energetic Studies of Cellular Biological Systems, Bristol, John Wright, 221 p.

Janssen, P.H., Yates, P.S., Grinton, B.E., Taylor, P.M., and Sait, M., 2002, Improved culturability of soil bacteria and isolation in pure culture of novel members of the divisions Acidobacteria, Actinobacteria, Proteobacteria, and Verrucomicrobia: Applied and Environmental Microbiology, v. 68, p. 2391-2396. doi: 10.1128/AEM.68.5. 2391-2396.2002.

Jones, S.E., and Lennon, J.T., 2010, Dormancy contributes to the maintenance of microbial diversity: Proceedings of the National Academy of Sciences of the United States of America, v. 107, p. 5881-5886. doi: 10.1073/pnas.0912765107.

Kawai, M., Yamaguchi, N., and Nasu, M., 1999, Rapid enumeration of physiologically active bacteria in purified water used in the pharmaceutical manufacturing process: Journal of Applied Microbiology, v. 86, p. 496-504. doi: 10.1046/j.1365-2672.1999.00689.x.

Kimura, T., and Takahashi, K., 1985, Calorimetric studies of soil microbes: quantitative relation between heat evolution during microbial degradation of glucose and changes in microbial activity in soil: Journal of General Microbiology, v. 131, p. 3083-3089. doi: 10.1099/00221287-131-11-3083.

Konhauser, K., 2007, Introduction to Geomicrobiology, Oxford, Blackwell Publishing Co., 433 p.

Lacelle, D., 2010, Discussion: "The biogenic origin of needle fibre calcite" by G. Cailleau et al. (2009), Sedimentology, 56, 1858-1875: Sedimentology, v. 57, p. 1147-1149. doi: 10.1111/j.1365-3091.2009. 01134.x.

Laiz, L., Groth, I., Schumann, P., Zezza, F., Felske, A., Hermosin, B., and Saiz-Jimenez, C., 2000, Microbiology of the stalactites from Grotta dei Cervi, Porto Badisco, Italy: International Microbiology, v. 3, p. $25-30$.

Muchová, M., Růžička, J., Julinová, M., Doležalová, M., Houser, J., Koutný, M., and Buňková, L., 2009, Xanthan and gellan degradation by bacteria of activated sludge: Water Science and Technology, v. 60, p. 965-973. doi: 10.2166/wst.2009.443.

Mulec, J., 2008, Microorganisms in hypogeon: examples from Slovenian karst caves: Acta Carsologica, v. 37, p. 153-160.

Mulec, J., Zalar, P., Hajna, N.Z., and Rupnik, M., 2002, Screening for culturable microorganisms from cave environments (Slovenia): Acta Carsologica, v. 31, no. 2, p. 177-187.

Northup, D.E., and Lavoie, K.H., 2001, Geomicrobiology of caves: a review: Geomicrobiology Journal, v. 18, p. 199-222. doi: 10.1080/ 01490450152467750

Parinkina, O.M., 1973, Determination of bacterial growth rates in tundra soils: Bulletins from the Ecological Research Committee (Stockholm), v. 17, p. $303-309$.

Pašić, L., Kovče, B., Sket, B., and Herzog-Velikonja, B., 2009, Diversity of microbial communities colonizing the walls of a Karstic cave in Slovenia: FEMS Microbiology Ecology, v. 71, p. 50-60.
Perrin, J., 2003, A conceptual model of flow and transport in a karst aquifer based on spatial and temporal variations of natural tracers [Ph.D. thesis]: Neuchatel, University of Neuchatel.

Phillips, S.E., Milnes, A.R., and Foster, R.C., 1987, Calcified filaments an example of biological influences in the formation of calcrete in south Australia: Australian Journal of Soil Research, v. 25, p. 405-428. doi: 10.1071/SR9870405.

Phillips, S.E., and Self, P.G., 1987, Morphology, crystallography and origin of needle fiber calcite in Quaternary pedogenic calcretes of south Australia: Australian Journal of Soil Research, v. 25, p. 429-444. doi: 10.1071/SR9870429.

Pirt, J.S., 1987, The energetics of microbes at slow growth rates: maintenance energies and dormant organisms: Journal of Fermentation Technology, v. 65, p. 173-177. doi: 10.1016/0385-6380(87) 90161-0.

Portillo, M.C., and Gonzalez, J.M., 2011, Moonmilk deposits originate from specific bacterial communities in Altamira Cave (Spain): Microbial Ecology, v. 61, p. 182-189. doi: 10.1007/s00248-010-9731-5.

Portillo, M.C., Gonzalez, J.M., and Saiz-Jimenez, C., 2008, Metabolically active microbial communities of yellow and grey colonizations on the walls of Altamira Cave, Spain: Journal of Applied Microbiology, v. 104 , p. 681-691. doi: 10.1111/j.1365-2672.2007.03594.x.

Qian, F., An, L., Wang, M., Li, C., and Li, X., 2007, Isolation and characterization of a xanthan-degrading Microbacterium sp. strain XT11 from garden soil: Journal of Applied Microbiology, v. 102, p. 1362-1371.

Rohwerder, T., Sand, W., and Lascu, C., 2003, Preliminary evidence for a sulphur cycle in Movile Cave, Romania: Acta Biotechnologica, v. 23, p. 101-107. doi: 10.1002/abio.200390000.

Rong, X.-M., Huang, Q.-Y., Jiang, D.-H., Cai, P., and Liang, W., 2007, Isothermal microcalorimetry: a review of applications in soil and environmental sciences: Pedosphere, v. 17, p. 137-145. doi: 10.1016/ S1002-0160(07)60019-8.

Sahin, N., 2003, Oxalotrophic bacteria: Research in Microbiology, v. 154, p. 399-407. doi: 10.1016/S0923-2508(03)00112-8.

Sahin, N., 2004, Isolation and characterization of mesophilic, oxalatedegrading Streptomyces from plant rhizosphere and forest soils: Naturwissenschaften, v. 91, p. 498-502. doi: 10.1007/s00114-004-0562-4.

Segawa, T., Yoshimura, Y., Watanabe, K., Kanda, H., and Kohshima, S., 2011, Community structure of culturable bacteria on surface of Gulkana Glacier, Alaska: Polar Science, v. 5, p. 41-51. doi: 10.1016/ j.polar.2010.12.002.

Shaw, W.V., and Hopwood, D.A., 1976, Chloramphenicol acetylation in Streptomyces: Journal of General Microbiology, v. 94, p. 159-166. doi: 10.1099/00221287-94-1-159.

Stomeo, F., Portillo, M.C., Gonzalez, J.M., Laiz, L., and Saiz-Jimenez, C., 2008, Pseudonocardia in white colonizations in two caves with Paleolithic paintings: International Biodeterioration \& Biodegradation, v. 62, p. 483-486. doi: 10.1016/j.ibiod.2007.12.011.

Tan, H., Deng, Z., and Cao, L., 2009, Isolation and characterization of actinomycetes from healthy goat faeces: Letters in Applied Microbiology, v. 49, p. 248-253. doi: 10.1111/j.1472-765X.2009.02649.x.

van Hees, P.A.W., Jones, D.L., and Godbold, D.L., 2002, Biodegradation of low molecular weight organic acids in coniferous forest podzolic soils: Soil Biology and Biochemistry, v. 34, p. 1261-1272. doi: 10.1016/S0038-0717(02)00068-8.

Wadsö, I., 2002, Isothermal microcalorimetry in applied biology: Thermochimica Acta, v. 394, p. 305-311. doi: 10.1016/S0040-6031(02)00263-0.

Wadsö, I., 2009, Characterization of microbial activity in soil by use of isothermal microcalorimetry: Journal of Thermal Analysis and Calorimetry, v. 95, p. 843-850. doi: 10.1007/s10973-008-9467-3. 